Goodbye to Darwin from a contemporary with vision

One night some 40 years ago, I was working late and alone in the library at the Marine Biology Laboratory at Woods Hole (in those days, the library never really closed), searching for something in the 1882 volume of Archiv für Protistenkunde. As I opened it, out fell a folded page from the magazine The Nation (still publishing today), dated 27 April 1882.

The page, headed 'Charles Darwin', was his obituary. As far as I know, it has not been reprinted or indexed in, for example, the Darwin archive at http:// darwin-online.org.uk. There is no indication of the author's identity, although it would be gratifying if it were his supporter and friend, the American botanist Asa Gray.

I was impressed by the prescient observations on Darwin. For example, the final paragraph points out "There can be little doubt that Mr. Darwin's name will go down in history as that of the greatest scientific inquirer and the most pregnant scientific thinker that has lived since Newton. Since the beginnings of modern learning, probably no single idea has wrought upon the minds of men with such rich and manifold results as the idea of 'natural selection'; and it is evident that what we have already seen is but an earnest of vastly more that is to come."

Richard Kool School of Environment and Sustainability, Royal Roads University, Victoria, British Columbia V9B 5Y2, Canada

e-mail: rick.kool@royalroads.ca

\section{Global Darwin: long kept under wraps in Pakistan}

Marwa Elshakry's Opinion article (Nature 461, 1200-1201; 2009, and see go.nature.com/97zlyr) makes no mention of the conflict of Darwin's ideas with popular religious beliefs in some conservative societies across the eastern world. There, the writings and thoughts of intellectuals, however influential, are no match for traditional religion.

For example, in Pakistan it was not until 2002 that a chapter on evolution was included for the first time in a school textbook, as a result of the federal government's educational reforms. The earlier decades of attempts to suppress scientific ideas were certainly not "enchanting".

Elshakry makes reference to Muhammad lqbal, the Muslim thinker and reformer from early last century. Although lqbal sought to challenge the traditional interpretation of religious beliefs and to understand religious principles in light of modern scientific thought, he avoided any direct mention of evolution or natural selection in his Urdu and Farsi writings. This was not because he was unaware of Darwin's works, but probably because he realized his audience was not yet ready to appreciate the significance of these ideas. Given their background of widespread illiteracy and poverty, deep-rooted social and religious conservatism, and colonial rule, religion was these people's last hope - and it was not the time to take that hope away.

Saheeb Ahmed Kayani National University of Sciences and Technology, Islamabad-44000, Pakistan e-mail: saheebk@ceme.nust.edu.pk

\section{Global Darwin: ideas blurred in early eastern translations}

The early diffusion of Darwin's ideas into China resulted in multiple interpretations, imperfect translations and unsatisfactory terminology, as James Pusey notes in his Opinion article (Nature 462, 162-163; 2009). However, he inadvertently implies that it was the Chinese scholar Yan Fu who translated 'evolution' as jinhualun, which means 'theory of progressive change'.

In fact, the word jinhualun originated in Japan in the 1870s, gaining popularity in China only after appearing in Ma Junwu's later translation of Darwin's The Origin of Species.

Instead, Yan Fu coined the term tianyanlun. The Chinese words tian and yan are layered in meaning, with tian translatable as 'heaven' and yan as 'development' or 'performance', among other concepts. But most would agree that tian corresponds nicely to the English word 'nature', whereas yan in this context denotes 'evolution'.

So, 'the theory of natural evolution' was Yan's preferred translation - a much more agreeable term, whether or not its alternative meanings are included.

David Flannery Department of International Studies,

Macquarie University, Sydney, New South Wales 2109, Australia e-mail: david.flannery@students. mq.edu.au

Readers may comment on the Global Darwin series at go.nature.com/97zlyr.

\section{Don't forget the artists when studying perception of art}

Martin Kemp in Books \& Arts (Nature 461, 882-883; 2009) suggests using functional neuroimaging to study the viewing and reception of artworks. But such direct measures of brain activity allow only for correlations between brain responses and the task of the viewer.

Clinical neuropsychologists have already studied the consequences of brain damage on cognition more directly. Insight into neurocognitive factors underlying art-making has come from, for instance, the effects of dementia on the abstract expressionist William de Kooning (1904-97) and of stroke on the German artists Lovis Corinth
(1858-1925) and Otto Dix (1891-1969). Some milder conditions can even enhance productivity and creativity. For example, the metaphysical art of Giorgio de Chirico (1888-1978)

may have been inspired by migraine or epilepsy.

Kemp focuses entirely on the beholder, as though - to paraphrase the French philosopher Roland Barthes (Aspen 5-6; 1967) - the birth of the viewer must be at the cost of the death of the artist. However, art historians and neuroscientists also need to take into account the maker and the making of artworks - a collaboration that is successfully being developed in the Swiss Artists-in-Labs programme (www.artistsinlabs. ch/english/index.htm).

Olaf Blanke, Luca Forcucci, Sebastian Dieguez Laboratory of Cognitive Neuroscience, Brain Mind Institute, École Polytechnique Fédérale de Lausanne, Station 19, 1015 Lausanne, Switzerland e-mail: olaf.blanke@epfl.ch

\section{How much are we willing to pay for a fossil?}

The outrage expressed by Elwyn Simons and others over the sale of a 47-million-year-old fossil for an enormous sum (Nature 460, 456; 2009) may not be altogether justified.

A fossil's intrinsic value relates to its preservation, rarity, scientific interest and completeness.

Arguably, this may be reflected as a commercial value to museums or private collectors.

The price a fossil is likely to fetch is of considerable interest to modern Chinese farmers, for example, as it was to their European predecessors around Bolca in the Italian Alps and Messel in Germany. Their excavations are often crude and can damage the fossil, but they still expect payment from interested professionals.

Worldwide closure of the 